\title{
UPAYA MENINGKATKAN VOLUME PENJUALAN PADA PRODUK MADU TERNAK P9 DI DESA PARSANGA
}

\author{
Fahrul Noerrahman ${ }^{1}$, Miftahol Arifin ${ }^{2}$ \\ ${ }^{1-2}$ Program Studi Manajemen, Universitas Wiraraja, Madura \\ 른.1nr@gmail.com, ${ }^{2}$ miftaholarifin@wiraraja.ac.id
}

\begin{abstract}
The problem examined in this thesis is because there is a problem in this research, in terms of market share of livestock honey, it is very difficult, the possibility of people still do not know the benefits or efficacy of honey itself and for natural honey, the target market is quite narrow, because the price is very high, but this natural honey has a long lasting period that can last for years. And also in the sale of livestock honey there are many problems when shipping far outside the city, because of every purchase there must be one cracked bottle in its packaging, and this is a problem that is being faced by P9 honey farmers in Parsanga Village. From the above analysis, researchers are interested to see how to increase sales volume. This makes the researcher raise the title Efforts to Increase Sales Volume on P9 Honey Products in ParsangaVillage. In answer these problem, researthers used descriptive qualitativ research. In this case, which is the focus of sales volume research, in this study researthers used a purposive sampling techniqu, consisting of key informants and supporting informants. The results of the study show that efforts to increase sales volumes affect the income of this livestock honey business, to achieve the target there must be steps that are passed or carried out in order to increase the sales volume of this livestock honey.
\end{abstract}

Keywords : Increase sales volume, Honey Products

\begin{abstract}
ABSTRAK
Masalah yang diteliti dalam skripsi ini yaitu dikarenakan terdapat masalah dalam penelitian ini yaitu dari segi pangsa pasar madu ternak ini sangatlah sulit kemungkinan orang masih belum tau untuk manfaat atau khasiat dari madu itu sendiri dan untuk madu alami target pasarnya cukup sempit, dikarenakan harganya yang sangat tinggi, namun madu alami ini memiliki jangka waktu tahan lama yang bisa bertahan bertahun-tahun. Dan juga dalam penjualan madu ternak banyak sekali mengalami kendala saat melakukan pengiriman jauh ke luar kota, karena dari setiap pembelian pasti ada salah satu botol yang pecah dalam pengemasannya, dan ini merupakan permasalah yang sedang di hadapi oleh peternak madu P9 di Desa Parsanga Dari analisis di atas peneliti tertarik untuk melihat bagaimana upaya meningkatkan volume penjualan. Hal ini menjadikan peneliti mengangkat judul Upaya Meningkatkan Volume Penjualan Pada Produk Madu Ternak P9 di Desa Parsanga. Dalam menjawab permasalahan tersebut, peneliti menggunakan teknik purposive sampling, yang terdiri dari informan kunci dan informan pendukung. Hasil peneliti menunjukkan bahwasannya upaya dalam meningkatkan volume penjualan berpengaruh terhadap pendapatan dari usaha madu ternak ini, untuk mencapai target maka harus ada langkah langkah yang diterapkan yaitu memperbaiki kualitas dari produk dan kemasan, guna meningkatkan dari volume penjualan madu ternak ini menjadi meningkat.
\end{abstract}

Kata Kunci: Menigkatkan Volumen Penjualan, Madu Ternak

\section{PENDAHULUAN}

Manajemen pemasaran adalah suatu iilmu yang memiliki makna penting di dalam dunia usaaha, berjalan dengan majunya teknologi dalam berbagi bidang menuntut kita ataupun perusahaan agar selalu berkompetisi dalam mencapai tujuan yang telah di tentukan, yaitu untuk memperoleh keuntungan yang semaksimal mungkin dengan biaya yang di keluarkan itu seminimal mungkin. Banyaknya sarana dan prasarana dalam usaha mengakibatkan perusahaan harus lebih ditekankan untuk meningkatkan pemasaran yang ditujukan untuk memuaskan para konsumen. Pemasaran berfungsi sebagai jalannya suatu proses dimana perusahaan dapat menciptakan nilai bagi pelanggan dan juga dapat membangun hubungan yang baik, dengan tujuan mendapatkan loyalitas dan nilai dari pelanggan sebagai imbalannya. Adapun dalam kontek pemasaran hal yang 
penting atau pokok yaitu dengan memperhatikan dari segi kualitas maupun harga dan juga kemasannya.

Dalam penelitian ini, objek penelitian yang di pilih oleh peneliti adalah Madu Ternak P9 di Desa Parsanga, hal tersebut dilakukan untuk mengetahui bagaimana upaya meningkatkan volume penjualan pada produk madu ternah P9 di Desa Parsanga.

Pemilihan Madu Ternak P9 dikarenakan terdapat masalah dalam penelitian ini yaitu dari segi pangsa pasar madu ternak ini sangatlah sulit kemungkinan orang masih belum tau untuk manfaat atau khasiat dari madu itu sendiri dan untuk madu alami target pasarnya cukup sempit, dikarenakan harganya yang sangat tinggi, namun madu alami ini memiliki jangka waktu tahan lama yang bisa bertahan bertahun-tahun.

Juga dalam penjualan madu ternak banyak sekali mengalami kendala saat melakukan pengiriman jauh ke luar kota, karena dari setiap pembelian pasti ada salah satu botol yang pecah dalam pengemasannya, dan inimerupakan permasalah yang sedang di hadapi oleh peternak madu P9 di Desa Parsanga.

\section{METODOLOGI PENELITIAN}

Dalam penelitian ini, peneliti menggunakan metode penelitian kualitatif deskriptif, di mana cara kerjanya adalah penelitii menjadi instrumnt dari penelitian itu sendiri dengan tujuan untuk mengetahui upaya meningkatkan volume penjualan pada produk madu ternak P9 di desa Parsanga.

Objek dari penelitian ini adalah Madu Ternak P9, yang beralokasikan di Gang Gagak Kodas Desa Parsanga Kota Sumnep, KabupatenSumenep, Jawa Tmur, 69417.
Penelitian ini dilakukan sejak bulan Februari sampai dengan Juli 2020.

Data yang di dapatkan oleh peneliti merupakan jenis data berupa Data Subyek, Data Fisik dan Data Dokumenter.

Adapun informan dalam penelitan ini adalah Informan Kunci dan Informan Pendukung. Peneliti mengumpulkan data dengan cara melakukan wawancara kepada infroman utama, informan kunci, dan infroman pendukung yaitu pemelik madu ternak P9, sedangkan informan pendukungnya yaitu konsumen atau pembeli dari Madu Ternak P9 yang ada di desa Parsanga.

Beberapa hal yang dilakukan peneliti untuk memperkuat pemahaman sebelum melakukan pembahasan dan menganalisa adalah melakukan observas, wawancara, dan dokumentasi.

Analisis data yang dimaksudkan adalah melakukan analisis secara interaktif dan secara terus menerus hingga tuntas dan data-data yang di dapat sudah mencapai titik jenuh, yang meliputi:Reduksi data, Penyajiandata, Kesimpulan/Verifikasi, Uji Keabsahan Data.

\section{HASIL DAN PEMBAHASAN}

Madu ternak merupakan madu yang hasilkan dari lebah yang diiternakan. Jenis lebah ternak sngatlah banya jenisnya, sama halnya dengan madu ternak yang menjadi usaha pertama di Desa Parsanga yang mampu beternak lebah dengan menghasilkan banyak sekali madu sehingga madu tersebut dijual dengn harga yang lumayan mahal, berbicara tentang penjualan tentu saja ada strategi strategi khusus yang dilakukan oleh seorang pengusaha.

Dari hasil wawancara peneliti dapat menyimpulkan dari jawaban mereka yaitu 
dari informan kunci Bapak Inong Yaqin dan informan pendukung (Bapak Arvian, Bapak Abdurrahman dan Bapak Nurussalam) bahwa dalam penjualannya masih bersifat stagnan berjalan seperti biasanya, dari jawaban Bapak Inong Yaqin selaku informan kunci dapat dikertahui bahwa dari penjualan Madu Ternak tersebut masih bersifat musiman yaitu ketika musim penghujan hasil dari ternak tersebut melimpah yaitu bisa menghasilkan 100 botol per panen sehingga dapat menghasilkan penjualan yang lumayan tinggi yaitu dengan harga 125.000 perbotol, sedangkan ketika musim kemarau hasil dari madu ternak tersebut turun drastis yaitu hanya menghasilkan 65 sampai 70 botol madu saja, sehingga penjualanpun juga ikut berkurang.

Peneliti mencoba memberikan masukan kepada Bapak Inong Yaqin atau pemilik dari Madu Ternak tersebut untuk menamb ah upaya upaya meningkatkan volume penjualan, peneliti tidak bermaksud untuk menyudutkan Bapak Inong Yaqin selaku pemilik Madu Ternak P9 tersebut peneliti hanya saja memberikan masukan sederhana kepada Bapak Inong Yaqin selaku pemilik Madu Ternak terkait upaya upaya meningkatkan volume penjualan pada Madu Ternak P9 di Desa Parsanga.

Meski demikian Bapak Inong Yaqin disana berpotensi untuk menambah upayaupaya dalam meningkatkan volume penjualan pada Madu Ternak P9 tersebut karena memang pada dasarnya mereka sudah bisa menggunakan media sosial untuk promosi produk tersebut meskipun tidak terlalu banyak jaringan sosial media yang mereka gunakan sebelumnya.

Pemasaran yang merupakan salah satu dari kegiatan kegiatan pokok yang dilakukan oleh para pengusaha dalam usahanya dalam mempertahankan kelangsungan hidup usaha tersebut serta dapat memperoleh sebuah laba, dari upaya upaya yang dilakukan untuk meningkat volume penjualan akan juga berdampak kepada usahnya, jika upaya tersebut baik dalam usahanya benar dalam menjalankan upaya tersebut maka juga berdampak meningkatkan pada penjualan tersebut.

Dari hasil wawancara yang telah dilakukan oleh peneliti dapat disimpulkan bahwa Bapak Inong Yaqin sebagai informan kunci memaparkan bahwa dampak dari upaya upaya yang dilakukan sudah ada hasilnya, Bapak Inong Yaqin mengatakan bahwa dari promosi secara online sudah ada hasilnya yaitu menambahkan konsumen yang membeli produknya, dan lebih banyak lagi yang mengenal produknya tersebut, peneliti juga melanjutkan pertanyaan terkait dampak dari upaya promosi secara langsug dan online, Bapak Inong Yaqin berpendapat bahwa dampak yang sangat membuahkan hasil yang cukup besar yaitu degan menggunakan promosi melalui media sosial.

Upaya upaya dalam meningkatkan volume penjualan sebagai saran utama peneliti sudah dijelaskan diatas yaitu diantaranya memperluas pngsa pasar yaitu mempromosikan Madu Ternak P9 dengan tidak hanya menitipkan ke toko-toko terdekat di Desa Parsanga melainkan menitipkan produknya ke toko toko diluar desa atersebut tujuannya untuk dapat memeperkenalkan lebih banyak lagi kepada masyarakat diluar desa Parsanga adapun dampak yang kan didapat oleh Bapak Inong Yaqin tersebut yaitu dapat memperluar pangsa pasar ketika pemasarannya sudah meluas maka otomatis penjulan akan meningkat.

Upaya yang kedua yang dijelaskan 
oleh peneliti terkait meningkatkan volume penjualan yaitu mempertahankan kualitas produk, menjalin hubungan yang baik kepada konsumenya itu dengan cara bertutur kata yang baik merespon pembeli baik melalui media online ataupun secara langsung ketika konsumen sudahnyaman dengan produknya, pelayanan yang baik jelas memberikan pengaruh yang kuat bagi konsumen. Semakin baik pelayanan semakin nyaman bagi konsumen untuk menjadi pelanggan tetap, karena memang pada dasarnya kepercayaan dari konsumen itu sangat penting untuk keberlanjutan atau kelangsungan hidup usahanya.

Selanjutnya upaya yang terkahir yaitu strategi pada harga yaitu memberikan promosi harga kepada konsumen untuk pertama kali memperkenalkan produknya, dan melihat harga dari saingan usahanya untuk mempertimbangkan harga berapa yang di tetapka sebagai harga awal dari penjualan Madu Ternak P9 tersebut, ketika kepercayaan konsumen sudah baik maka harga berapapun konsumen tidak akan mempermaslahkan namun lebih baik untuk mempertimbankan harga untuk daya saing diluar ketika ada produk yan lebih murah daripada Madu Ternak P9 dan kualitas juga baik maka secara langsung konsumen akan berpindah ke produk lainnya, dengan mempertimbangkan harga pada produk ini maka akan berdampak pada volume penjualannya yaitu bisa mempertahankan konsumen yang akan berpindah keproduklainnya.

Adapun manfaat yang akan didapat oleh Bapak Inong Yaqin selaku pemilik dari dampak yang dihasilkan dari upaya upaya yng telah dijelaskn olehpenelitiyaitu yang pertama dapat memperluas pangsapasar, yang kedua dapat mempertahankan kepercayaan konsumen, dapat memperluas memperkenalkan produk dari Madu Ternak P9 di Desa Parsanga, dengan demikian pemilik Madu Ternak berpotensi untuk melakukan upaya upaya tersebut, tertarik karena memang ada dampak khusus dari usahanya selain dapat menjaga kualitas produknya bisa juga dapat mempertahankan keberlangsungan hidup usahanya.

\section{KESIMPULAN}

Berdasarkan penelitian dan pembahsan di bab iv dapat disimpulkanbahwa dalam meningkatkan volume penjualan ada beberapa upaya yang dilakukan sama halnya dengan upaya upaya yang dilakukan di Madu Ternak P9 di Desa Parsanga, dimana disana hanya menggunakan strategi yang sama dengan strategi pada umumnya yaitu upaya yang dilakukan hanya menggunakan media sosial saja dengan dua jenis media sosial yaitu hanya menggunakan whatshap dan facebook, namun disana sudah bisa mempertahankan kepercayaan konsumen dengan cara menjaga kualitas dari produk Madu Ternak P9 Di Desa Parsanga. Upaya yang dilakukan oleh peneliti terkait meningkatkan volume penjualan yaitu mempertahankan kualitas produk, menjalin hubungan yang baik kepada konsumen yaitu dengan cara bertutur kata yang baik merespon pembeli baik melalui media online ataupun secara langsung ketika konsumen sudah nyaman dengan produknya, pelayanan yang baik jelas memberikan pengaruh yang kuat bagi konsumen. Semakin baik pelayanan semakin nyaman bagi konsumen untuk menjadi pelanggan tetap, karena memang pada dasarnya kepercayaan dari konsumen itu sangat penting untuk keberlanjutan atau kelangsungan hidup usahanya. 


\section{DAFTAR PUSTAKA}

Dita. 2011, "Pengaruh Promosi Dan Brand Image (Citra Produk) Terhdap Loyalitas Pembelian Produk Pepssoden Di Ramayana Plaza Jalan Aksara Medan", Jurnal Keuangan Dan Bisnis, 3 (3), 221-233

Danang Suyoto. 2013, Dasar-Dasar Manajemen Pemasaran, Yogyakarta : PT Revika.

Ferreira Reis Dos Zonia.2019, “.Analysis of Business Marketing Strategy in anEffort to Increase the Sales Volume of Company $\mathrm{X}$ in Dili City, East Timor", Dalam Jurnal European Journal of Business and Management, Universitas School of Magister Management, Parahyangan Catholic University, Jl. Merdeka No.30, Bandung Indonesia., Vol.11, No.29, 2019, ISSN 2222-1905 (Paper) ISSN 2222-2839 (Online).

Handika Resta Made. 2018, "Strategi Pemasaran Bisnis Kuliner Menggunakan Influencer MelaluiMedia Sosial Instagram", Dalam Junal Manajemen dan Bisnis, Universitas Undiknas Graduate School Bali, Vol. 15, No. 2, Mei 2018,ISSN : 1829-8486.

Mulyani Elistiana Elis. 2015, “Analisis Determinasi Volume Penjualan Saham Dan Tingkat Bunga Terhadap Harga Saham", dalam Jurnal Ekonomi Manajemen, Universitas Siliwangi Tasikmalaya, Volume 1 Nomor 1 (November 2015) 15-21, ISSN 24772275.

Rahmat, Sopa, Faisal, Putri, Didin. 2018, "Peranan Promosi Terhadap Peningkatan Volume Penjualan Produk Rajutan di CV Konta Djaya Binong Jati”, Dalam Jurnal Pengabdian Kepada Masyarakat, Universitas BSI Bandung, Vol. 1 No.
2 Agustus 2018, Hal. 296-304, EISSN : 2614-6711.

Ratna Sari. 2016, "Peranan Periklanan Dan Personal Selling Terhadap Volume Penjulan Pada PT. Radio Citra Anak Siantar (CAS) 89,4 FM Pematang Siantar", Dalam Jurnal MAKER, Universitas Kristen Petra Surabaya, Vol. 2,No. 1, JUNI 2016, ISSN :25024434

Saputro Adi Gunawan. 2010, “ Dasar-Dasar Manajemen Pemasaran", Yogyakarta: PT Revika.

Theresia Pradiani. 2017, "Pengaruh Sistem Pemasaran Digtal Marketing Terhadap Penngkatan Volume Penjualan Hasil Industri Rumahan", Dalam Jurnal Pengaruh Sistem Pemasaran Digital Marketing, Universitas STIE ASIA Malang, VOLUME 11NOMOR 2 FEBRUARI 2017 : 46 -53. 